\title{
Strong SiC Porous Ceramic Obtained by Sintering of Reticulated Aligned SiC Nanowires
}

\begin{abstract}
ZHU Quan ${ }^{1,2,3}$, HU Jianbao ${ }^{1,2}$, YANG Jinshan ${ }^{1,2}$, ZHOU Haijun $^{1,2}$, DONG Shaoming ${ }^{1,2}$
(1. State Key Laboratory of High Performance Ceramics and Superfine Microstructure, Shanghai Institute of Ceramics, Chinese Academy of Sciences, Shanghai 200050, China; 2. Structural Ceramics and Composites Engineering Research Center, Shanghai Institute of Ceramics, Chinese Academy of Sciences, Shanghai 200050, China; 3. University of Chinese Academy of Sciences, Beijing 100049, China)
\end{abstract}

\begin{abstract}
High strength $\mathrm{SiC}$ porous ceramic with reticular pore structure is assembled by cross-lamination of layers comprised by aligned $\mathrm{SiC}$ nanowire (SiCNWs) struts printed through direct ink writing. SiCNWs networks exhibit a structure with highly interconnected porosity and an architecture formed by aligned SiCNWs struts. The effects of sintering temperature on the structures, phase evolutions and mechanical properties were studied. The high aspect ratio of SiCNWs was kept well at sintering temperature lower than $1900{ }^{\circ} \mathrm{C}$. The bulk density, porosity and median pore diameter of aligned SiCNWs porous ceramics sintered at $1850{ }^{\circ} \mathrm{C}$ were $1.49 \mathrm{~g} / \mathrm{cm}^{3}, 54.6 \%$ and $\sim 1 \mu \mathrm{m}$, respectively. Due to the effect of orientation and high strength of $\mathrm{SiC}$ nanowire struts, compressive strength of (245.5 \pm 0.7$) \mathrm{MPa}$ is achieved.
\end{abstract}

Key words: porous ceramic; $\mathrm{SiC}$; nanowire; additive manufacturing; orientation

Porous silicon carbide $(\mathrm{SiC})$ ceramics possess a unique combination of desirable properties, such as excellent high temperature strength, high chemical stability, high thermal shock stability, and outstanding oxidation resistance ${ }^{[1-2]}$. Light and porous $\mathrm{SiC}$ structures are of interest for a number of advanced technological applications, such as hot-gas or molten-metal filters, catalyst supports and others ${ }^{[3-5]}$.

Light weight with high strength is always desired demands for porous ceramics which depends on pore structure and the strength of wall materials. According to classifications of cellular topology, stretching-dominated structure has a larger load bearing capability through overall structure compared to bending-dominated structure ${ }^{[6-7]}$. Microarchitecture design enables stretchingdominated structure deform failure mode, which is an important method to prepare high strength cellular ceramics ${ }^{[8-9]}$. However, it is worth noting that the strength and stiffness of porous ceramic also scale with those of their wall or strut ${ }^{[10]}$. The struts without defects are desirable. Therefore, a good method to fabricate a strong, light porous $\mathrm{SiC}$ ceramic is through the assembly of thin, monocrystalline $\mathrm{SiC}$ nanowires or whiskers. In addition, oriented nanowires are better than random nanowires to improve the mechanical strength ${ }^{[11]}$. That design is in line with structure of bone, a natural lightweight strong material which is comprised of nano-scale oriented blocks in principle stress direction ${ }^{[12]}$.

Inspired by high strut strength and orientation architecture, here we presented a novel method for $\mathrm{SiC}$ porous ceramic fabrication where reticulate structure was directly comprised of oriented $\mathrm{SiC}$ nanowires. This was realized through crossed layer-by-layer direct ink printing. SiC nanowires in each filament were aligned in the streamwise direction due to shear flow through nozzle tip. The structure and morphology were characterized, and the mechanical properties of the porous $\mathrm{SiC}$ nanowire networks were investigated.

\section{Experimental procedure}

$\beta$-SiC nanowires with diameter in $0.1-0.6 \mu \mathrm{m}$, length in $50-100 \mu \mathrm{m}$, purity higher than $96 \%$, density of $3.21 \mathrm{~g} / \mathrm{cm}^{3}$, and aspect ratio of 100-200 (Changsha Sinet Advanced Materials Co., Ltd. Changsha, China) are used as raw materials. $\mathrm{SiC}$ nanowires (SiCNWs) were dispersed in

Received date: 2020-05-15; Revised date: 2020-06-09; Published online: 2020-07-10

Foundation item: Key Research Program of Frontier Science, Chinese Academy of Sciences (QYZDY-SSW-JSC031); Key Program of the Chinese Academy of Sciences (ZDRW-CN-2017-1, ZDRW-CN-2019-01)

Biography: ZHU Quan(1986-), female, PhD candidate. E-mail: zhuquan03@126.com

祝 泉(1986-), 女, 博士研究生. E-mail: zhuquan03@126.com

Corresponding author: HU Jianbao, associate professor. E-mail: hujianbao@mail.sic.ac.cn 胡建宝, 副研究员. E-mail: hujianbao@mail.sic.ac.cn 
deionized water part by part using ultrasonic method to ensure homogeneous dispersion. $\mathrm{Al}_{2} \mathrm{O}_{3}$ and $\mathrm{Y}_{2} \mathrm{O}_{3}\left(m\left(\mathrm{Al}_{2} \mathrm{O}_{3}\right)\right.$ : $\left.m\left(\mathrm{Y}_{2} \mathrm{O}_{3}\right)=3: 2\right)$ with $15 \mathrm{wt} \%$ of the $\mathrm{SiC}$ nanowires were added to promote sintering. The volume fraction of $\mathrm{SiC}$ nanowires was $10 \%$. 2.5wt \% hydroxypropyl methylcellulose solution (25wt\% water) and $0.04 \%$ polyethyleneimine ( $5 \mathrm{wt} \%$ water) was added in the dispersed $\mathrm{SiC}$ nanowire slurry. The ink was mixed for $1 \mathrm{~h}$ by mechanical stirring (300 r/min).

A 3D-Bioprinter ${ }^{\mathrm{TM}}$ System (Regenovo, Shining 3D Tech Co., Ltd, China) equipped with a pressurized paste extrusion system was used to fabricate the samples. The inks were loaded into $100 \mathrm{~mL}$ syringe with a plunger. Printing nozzles with diameter in $320 \mu \mathrm{m}$ were used to produce SiC nanowire filaments. A constant pressure was applied to induce the ink flow through the nozzle. The writing speed was set at $25 \mathrm{~mm} / \mathrm{s}$. After printing, the samples were dried for $24 \mathrm{~h}$ and calcined at $550{ }^{\circ} \mathrm{C}$ for $1 \mathrm{~h}$ in air. The samples were subsequently sintered in $\mathrm{Ar}$ at a heating rate of $5{ }^{\circ} \mathrm{C} / \mathrm{min}$ up to 1800,1850 and $1900{ }^{\circ} \mathrm{C}$ for $1 \mathrm{~h}$.

The morphologies of the scaffolds before and after sintering were investigated using scanning electron microscope (S4800, Hitachi, Tokyo, Japan). The apparent porosity, pore size distributions and bulk density of sintered SiC porous ceramics were examined by a mercury porosimetry (Autopore IV9510, USA). The out-of-plane compressive strength was measured using a test machine (Instron-5592). Five rectanglular samples with size of $4 \mathrm{~mm} \times 6 \mathrm{~mm} \times 6 \mathrm{~mm}$ for each sample were machined and tested. The load was applied on the two parallel surfaces at a crosshead speed of $0.5 \mathrm{~mm} / \mathrm{min}$.

\section{Results and discussion}

\subsection{Microstructure}

The printed scaffold consists of uniform oriented $\beta$-SiC nanowires along printing direction as shown in Fig. 1(a,b), which is aroused by the shear flow of slurry through nozzle tip. The Lotgering orientation factor of $f_{(11)}$ of printed SiCNWs is about $0.956^{[13]}$. SiCNWs possess good crystallinity except for a small diffraction peak at $2 \theta=33.64^{\circ}$. It is a kind of stack fault ${ }^{[13]}$. The as-recieved SiCNWs have rough surface and heterogeneous morphology.

About $46.9 \mathrm{vol} \%$ shrinkages of printed SiCNW networks occurred after drying. The printed SiCNW networks were sintered at 1800,1850 and $1900{ }^{\circ} \mathrm{C}$. Further shrinkages are observed after sintering. Compared to the printed samples before drying, the volume shrinkage ratios of SiCNW networks sintered at 1800, 1850 and
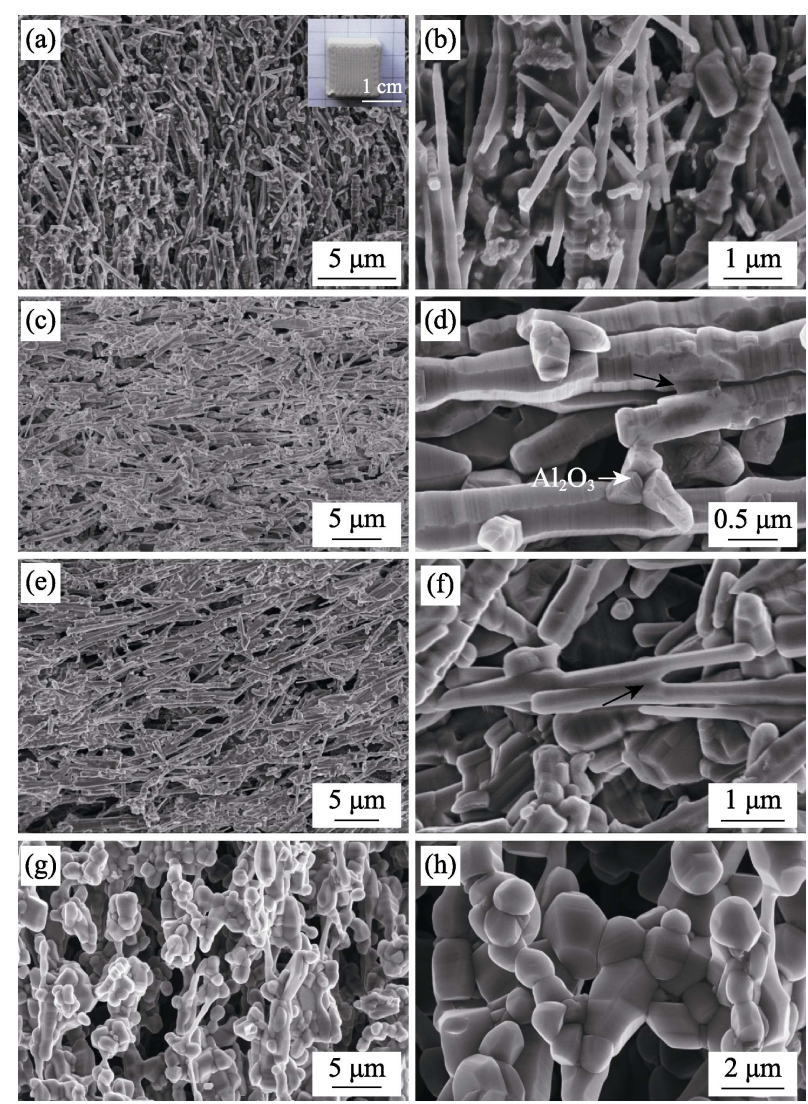

Fig. 1 Morphologies of samples with different magnifications (a, b) Before sintering, and sintered at (c, d) 1800 , (e, f) 1850 and (g, h) $1900{ }^{\circ} \mathrm{C}$. The insert in (a) is the appearance of printed SiCNWs scaffold

$1900{ }^{\circ} \mathrm{C}$ are about $74.0 \%, 79.8 \%$ and $83.6 \%$, respectively. The typical morphologies after sintering are shown in Fig. 1(c-h). Shortening and coarsening of SiC nanowires occurred after high temperature sintering. The high aspect ratio of SiCNWs was kept well at sintering temperature lower than $1900{ }^{\circ} \mathrm{C}$. The sintered SiCNWs networks exhibit a structure with highly interconnected pore and an architecture formed by aligned SiCNWs struts. The wall thickness is of the order of SiCNWs diameter $(<500 \mathrm{~nm})$. The adjacent $\mathrm{SiC}$ nanowires were sintered together and the remaining liquid phase can be seen in Fig. 1(d, f). Most of SiCNWs were changed to particles after sintered at $1900{ }^{\circ} \mathrm{C}$. Fig. 2 shows the pore distribution of porous SiCNWs networks sintered at 1800 and $1850{ }^{\circ} \mathrm{C}$. The pore size distribution of sample sintered at $1900{ }^{\circ} \mathrm{C}$ was not tested due to its low strength. Sintered SiCNW networks showed uniform pore size distribution. The pore dimensions are distributed between 0.5 and $1 \mu \mathrm{m}$, accounting for $86.5 \mathrm{vol} \%$ pores. The density, porosity and median pore diameter changed from $1.25 \mathrm{~g} / \mathrm{cm}^{3}, 60.5 \%, 1121 \mathrm{~nm}$ to $1.49 \mathrm{~g} / \mathrm{cm}^{3}$, $54.6 \%, 994 \mathrm{~nm}$ after sintered at 1800 and $1850{ }^{\circ} \mathrm{C}$, respectively. 

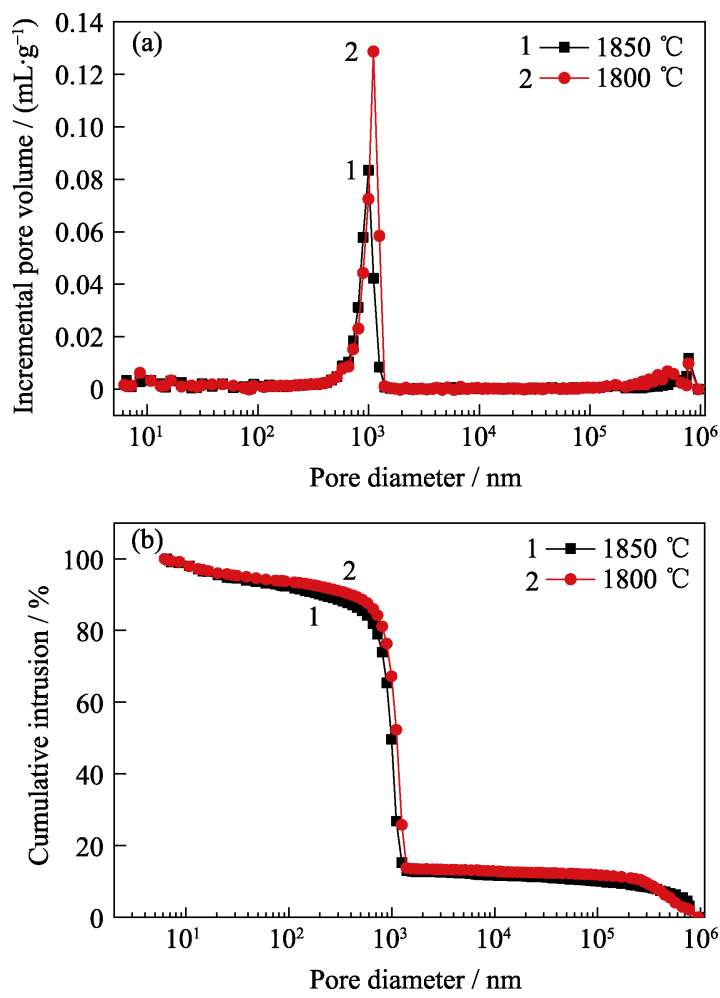

Fig. 2 Pore size distributions of $\mathrm{SiC}$ porous ceramics sintered at 1800 and $1850{ }^{\circ} \mathrm{C}$

Fig. 3 shows the corresponding XRD patterns of SiCNWs networks after sintering. The SiCNWs network sintered at $1800{ }^{\circ} \mathrm{C}$ shows no change in the phase composition except for the crystallization of sintering additives compared to the as-received $3 \mathrm{C}-\mathrm{SiC}$ SiCNWs.

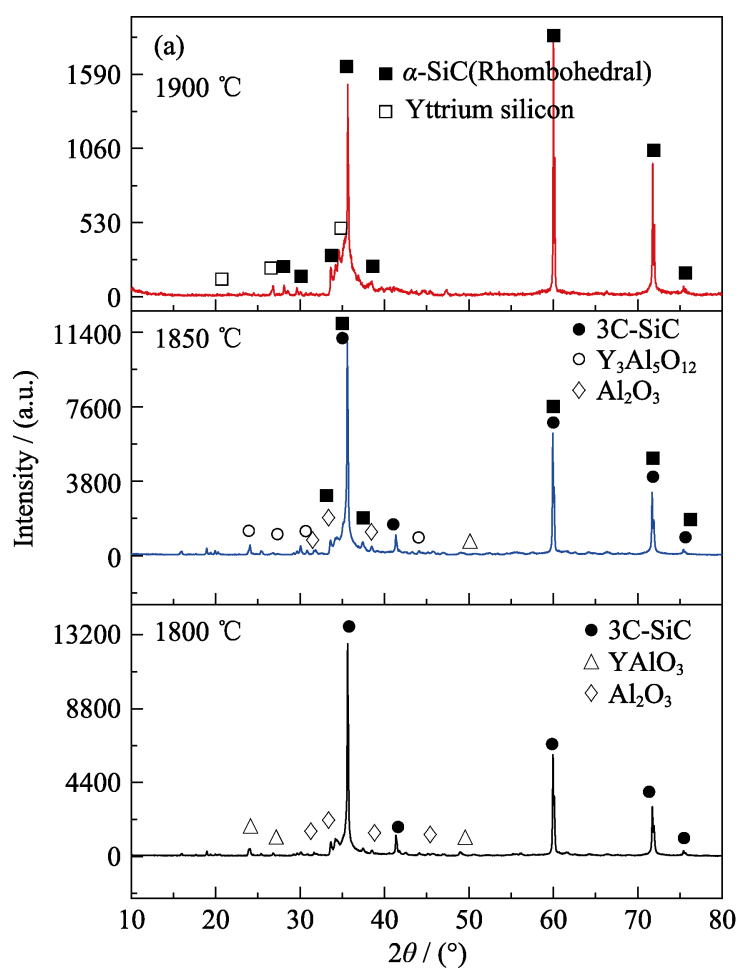

When sintered at $1850{ }^{\circ} \mathrm{C}$, both $\alpha$-SiC (Rhombohedral) and $3 \mathrm{C}-\mathrm{SiC}$ are detected. While sintered at $1900{ }^{\circ} \mathrm{C}$, only $\alpha$-SiC (Rhombohedral) is found, which indicates the $3 \mathrm{C}-\mathrm{SiC}$ nanowires all change to $\alpha-\mathrm{SiC}$, corresponding to the particle morphology as shown in Fig. 1(g, h). Pure SiCNWs without sintering additives show good phase stability after heat-treatment from $1800{ }^{\circ} \mathrm{C}$ to $1950{ }^{\circ} \mathrm{C}$ (Fig. 3(a)). The sintering additives promote the phase transformation from $\beta$-SiC into $\alpha-\mathrm{SiC}^{[14]}$ and morphology change from nanowires into particles.

\subsection{Mechanical properties}

Sintered SiCNWs networks displayed cellular rupture which commonly occurred in ceramic foams during compressive test as shown in Fig. 4. The wavy platform after the highest load value indicates gradual failure of porous structure. Samples with nanowire-like struts possess much higher strength than those with particle-like struts $((37.5 \pm 6) \mathrm{MPa})$. The SiCNWs porous ceramic sintered at $1850{ }^{\circ} \mathrm{C}$ showed the highest compressive strength $((245.5 \pm$ $0.7) \mathrm{MPa}$ ). Samples sintered at $1800{ }^{\circ} \mathrm{C}$ mostly fail at the junction between nanowires (Fig. 4(b)) due to the incompletely sintering, which can be confirmed by the residual $\mathrm{Al}_{2} \mathrm{O}_{3}$ as shown in Fig. 1(d). When sintered at $1850{ }^{\circ} \mathrm{C}$, failure events of SiCNWs are observed which indicated by arrows in Fig. 4(c). When SiCNWs struts changed to particle struts which sintered at $1900{ }^{\circ} \mathrm{C}$, intergranular fracture dominates the main failure modes as shown in Fig. 4(d).

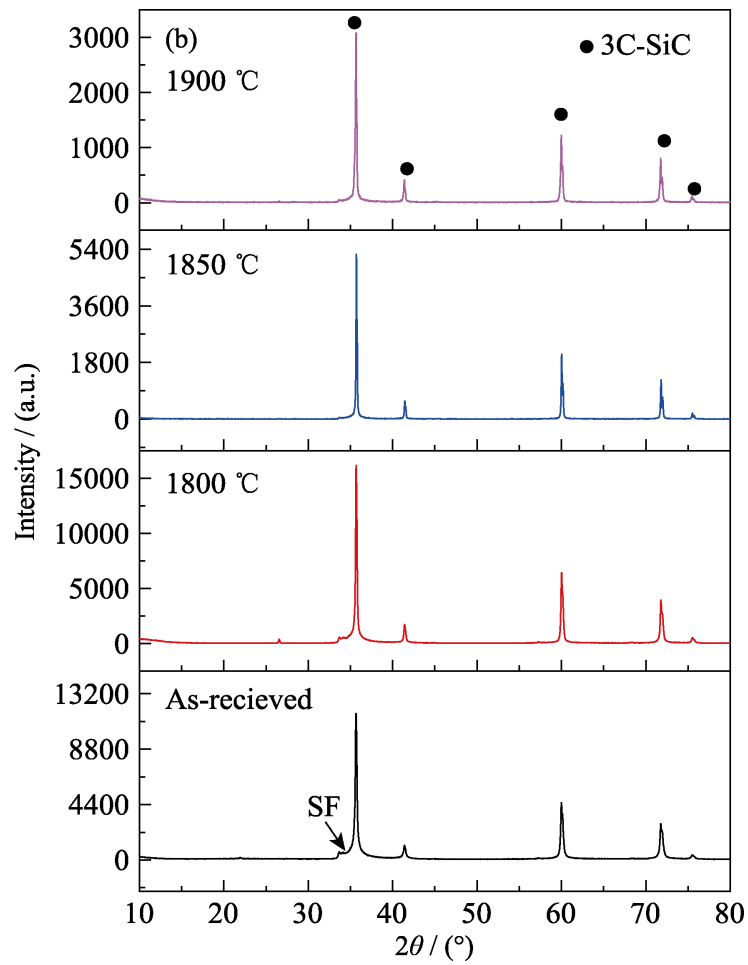

Fig. 3 XRD patterns of SiC porous ceramics sintered at different temperatures (a) and SiCNWs treated at different temperatures (b) 

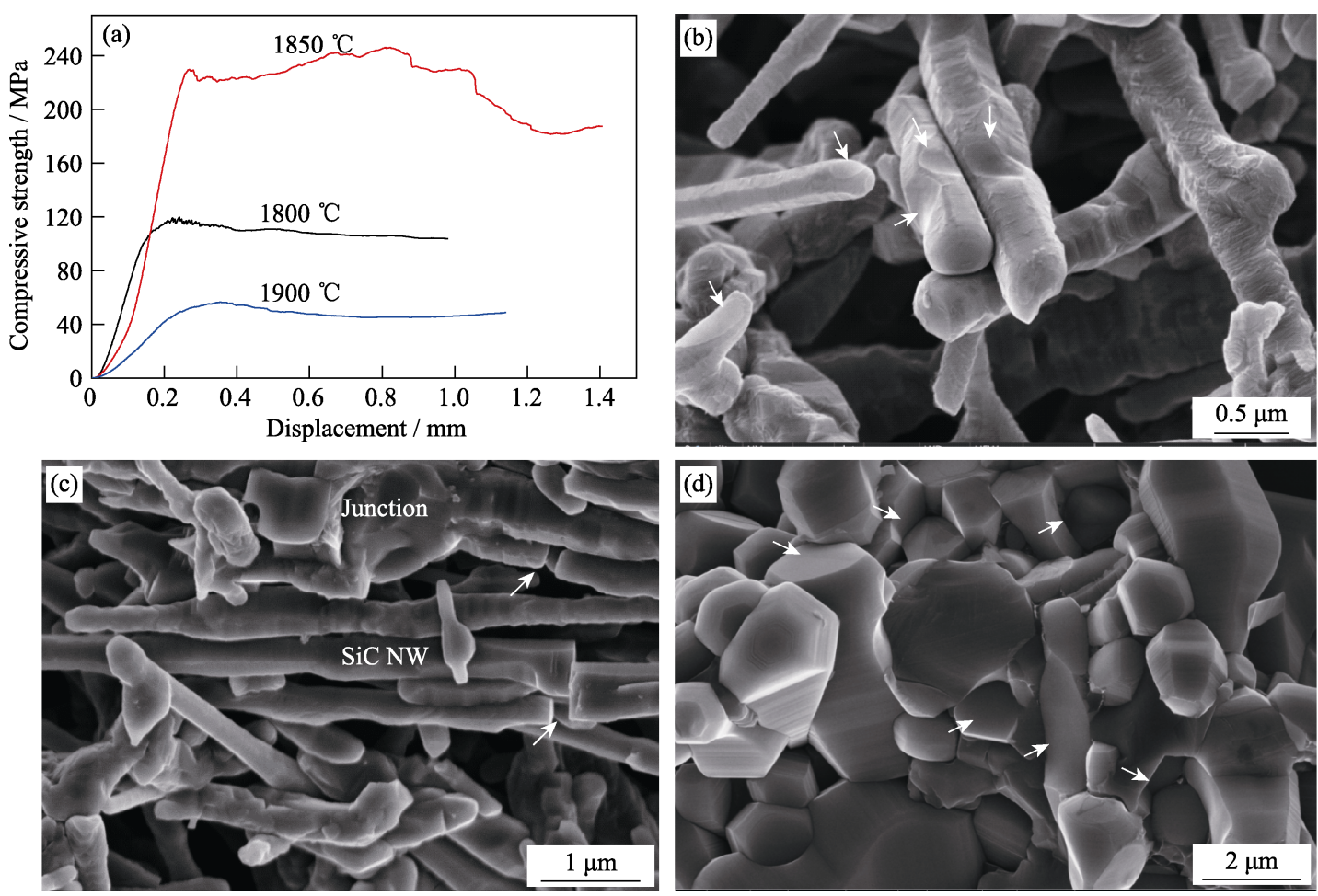

Fig. 4 Compressive strength-strain curves of $\mathrm{SiC}$ porous ceramic sintered at different temperatures (a) and fracture modes of SiC porous ceramics sintered at 1800 (b), 1850 (c) and $1900{ }^{\circ} \mathrm{C}$ (d)

The SiCNWs networks show higher strength compared to other porous $\mathrm{SiC}$ ceramics with comparable porosity ${ }^{[15-20]}$ as shown in Fig. 5. The mechanical properties depend on its architecture and the strength of the struts ${ }^{[10]}$. The struts in this work are oriented SiCNWs and of the order of the nanowire diameter. 3D printing ceramic with layered orthotropic construction is considered to behave in a bending-dominated manner ${ }^{[8]}$. The most widely used models to predict the mechanical response of cellular materials were developed by Gibson and Ashby ${ }^{[21]}$. Open cell model was used to discuss the compressive strength, described by equation (1):

$$
\frac{\sigma}{\sigma_{\mathrm{fs}}} \approx 0.2\left(\frac{\rho^{*}}{\rho_{0}}\right)^{3 / 2}
$$

Where $\sigma$ is the compressive strength of the porous composite; $\sigma_{\mathrm{fs}}$ is the fracture strength of the wall material (struts); $\rho^{*}$ is the density of the porous ceramic and $\rho_{0}$ is the density of struts.

The bending strength of SiCNWs struts sintered at $1850{ }^{\circ} \mathrm{C}$ according to equation (1) reaches $\sim 3.9 \mathrm{GPa}$, which is much larger than those reported for sintered ceramics and comparable to those estimated for struts of ceramics microlattices ${ }^{[22]}$. High strength of SiCNWs struts contributes to the high compressive strength of SiCNWs networks. In addition, aligned structure can take the full advantage of load-carrying capacity of nanowires because tensile stress present a maximum at the centers of the free segments of struts aligned along printed direction ${ }^{[23]}$.

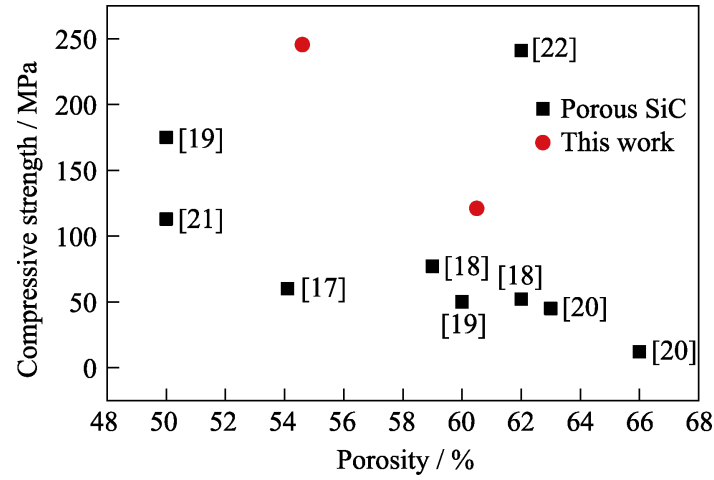

Fig. 5 Comparison of the compressive strength of SiCNW networks with other porous $\mathrm{SiC}$ ceramics

Numbers in square brackets represent the serial number of refered documents

The experimental results and calculated strength of SiCNWs are lower than expectations. This is attributed to the facts that degradation of SiCNWs during sintering and failure at junctions as it has been observed in the XRD and SEM tests.

\section{Conclusions}

Size-dependent effects of struts strength and architecture benefits from orientation advantages were designed and investigated. The two features are realized by $\mathrm{SiC}$ nanowires and assembling of aligned $\mathrm{SiC}$ nanowires struts with cross-lamellar structure by direct ink printing. Although stretching-dominated deform mode is not specially designed here, an orientated structure combined with strong 
$\mathrm{SiC}$ nanowire struts provides higher strength than other porous $\mathrm{SiC}$ ceramics with comparable porosity.

\section{References:}

[1] SHE JI-HONG, OHJI T, DENG ZHEN-YAN. Thermal shock behavior of porous silicon carbide ceramics. Journal of the American Ceramic Society, 2002, 85(8): 2125-2127.

[2] LIU SHI-FENG, ZENG YU-PING, JIANG DONG-LIANG. Effects of $\mathrm{CeO}_{2}$ addition on the properties of cordierite-bonded porous $\mathrm{SiC}$ ceramics. Journal of the European Ceramic Society, 2009, 29(9): 1795-1802.

[3] PASTILA P H, HELANTI V, NIKKILA A P, et al. Environmental effects on microstructure and strength of SiC-based hot gas filters. Journal of the European Ceramic Society, 2001, 21(9): 1261-1268.

[4] DAS D, KAYAL N, MARSOLA G A, et al. Recycling of coal fly ash for fabrication of elongated mullite rod bonded porous $\mathrm{SiC}$ ceramic membrane and its application in filtration. Journal of the European Ceramic Society, 2020, 40: 2163-2172.

[5] BETKE U, LIRB A. Micro-macroporous composite materialspreparation techniques and selected applications: a review. Advanced Engineering Materials, 2018, 20: 1800252

[6] DESHPANDE V S, ASHBY M F, FLECK N A. Foam topology bending versus stretching dominated architectures. Acta Materialia, 2001, 49(6): 1035-1040.

[7] ASHBY M F. The properties of foams and lattices. Philosophical Transactions of the Royal Society A, 2006, 364: 15-30.

[8] BAUER J, HENGSBACH S, TESARI I, et al. High-strength celluar ceramic composites with 3D microarchitecture. PNAS, 2014, 111(7): $2453-2458$.

[9] KAUR M, YUN T G, HAN S M, et al. 3D printed stretchingdominated micro-trusses. Materials and Design, 2017, 134: 272-280.

[10] FERRARO C, GARCIA-TUNON E, ROCHA V G, et al. Light and strong SiC networks. Advanced Functional Materials, 2016, 26: 1636-1645.

[11] WANG CHANG-AN, HUANG YONG, ZHAI HONG-XIANG. The effect of whisker orientation in $\mathrm{SiC}$ whisker-reinforced $\mathrm{Si}_{3} \mathrm{~N}_{4}$ ceramic matrix composites. Journal of the European Ceramics Society, 1999, 19: 1903-1909.

[12] MEYERS M A, CHEN PO-YU, LIN YU-MIN, et al. Biological materials: structure and mechanical properties. Progress in Materials
Science, 2008, 53: 1-206.

[13] ZHU QUAN, DONG XIANG, HU JIAN-BAO, et al. High strength aligned $\mathrm{SiC}$ nanowire reinforced $\mathrm{SiC}$ porous ceramics fabricated by $3 \mathrm{D}$ printing and chemical vapor infiltration. Ceramics International, 2020, 46: 6978-6983.

[14] NADER M, ALDINGER F, HOFFMANN M J. Influence of the $\alpha / \beta \mathrm{SiC}$ phase transformation on microstructural development and mechanical properties of liquid phase sintered silicon carbide. Journal of Materials Science, 1999, 34: 1197-1204.

[15] EOM J H, KIM Y W, SONG I H. Microstructure and properties of porous silicon carbide ceramics fabricated by carbothermal reduction and subsequent sintering process. Materials Science and Engineering: $A$, 2007, 464(1/2): 129-134.

[16] KIM Y W, EOM J H, GUO YAN-TING, et al. Processing of open-cell silicon carbide foams by steam chest molding and carbothermal reduction. Journal of the American Ceramics Society, 2011, 94(2): 344-347.

[17] EOM J H, KIM Y W, SONG I H, et al. Processing and properties of polysiloxane-derived porous silicon carbide ceramics using hollow microspheres as templates. Journal of the European Ceramics of Society, 2008, 28: 1029-1035.

[18] EOM J H, KIM Y W. Effect of additive composition on microstructure and strength of porous silicon carbide ceramics. Journal of Materials Science, 2009, 44: 4482-4486.

[19] SHIMAMURA A, FUKUSHIMA M, HOTTA M, et al. New approach for macro porous $\mathrm{RB}-\mathrm{SiC}$ derived from $\mathrm{SiC} /$ Novolactype phenolic composite. Journal of the American Ceramics Society, 2016, 99: 440-444.

[20] VARELA-FERIA F M, MARTINEZ-FERNANDEZ J, ARELLANOLOPEZ A R, et al. Low density biomorphic silicon carbide: microstructure and mechanical properties. Journal of the European Ceramics Society, 2002, 22: 2719-2725.

[21] GIBSON L J, ASHBY M F. Cellular Solids: Structure and Properties, 2ed. Cambridge University, 1997.

[22] JANG DONG-CHAN, MEZA L R, GREER F, et al. Fabrication and deformation of three-dimensional hollow ceramic nanostructures. Nature Materials, 2013, 12: 893-898.

[23] MIRANDA P, PAJARE A, SAIZ E, et al. Fracture mode under uniaxial compression in hydroxyapatite scaffolds fabricated by robocasting. Journal of Biomedial Materials Research Part A, 2007, 83(3): 646-655.

\section{采用定向 $\mathrm{SiC}$ 纳米线烧结制备高强多孔 $\mathrm{SiC}$ 陶瓷}

$$
\text { 祝 泉 }{ }^{1,2,3} \text {, 胡建宝 }{ }^{1,2} \text {, 杨金山 }{ }^{1,2} \text {, 周海军 }{ }^{1,2} \text {, 董绍明 }{ }^{1,2}
$$

(1. 中国科学院高性能陶瓷和超微结构国家重点实验室, 上海 200050; 2. 中国科学院 上海硅酸盐研究所, 结构 陶瓷与复合材料工程研究中心, 上海 200050; 3. 中国科学院大学, 北京 100049)

摘 要: 利用直接墨水打印方法制备了由定向 $\mathrm{SiC}$ 纳米线交错叠层组成的具备网络状孔隙结构的高强 $\mathrm{SiC}$ 多孔陶 瓷。制备的碳化硅多孔陶瓷具有高的通孔结构和完全由定向 $\mathrm{SiC}$ 纳米线组装而成的结构特征。研究了烧结温度对 定向 $\mathrm{SiC}$ 纳米线多孔陶瓷的微观结构、相组成演变及力学性能的影响。研究结果表明: 烧结温度低于 $1900{ }^{\circ} \mathrm{C}$ 时, $\mathrm{SiC}$ 纳米线能保持高长径比; $1850{ }^{\circ} \mathrm{C}$ 烧结制备的定向 $\mathrm{SiCNWs}$ 多孔陶瓷的密度、气孔率和中位孔径分别为 $1.49 \mathrm{~g} / \mathrm{cm}^{3}$ 、 $54.6 \%$ 和 $1 \mu \mathrm{m}$ 。得益于 $\mathrm{SiC}$ 纳米线的高强度以及取向排布, $\mathrm{SiC}$ 纳米线多孔陶瓷的压缩强度高达 $(245.5 \pm 0.7) \mathrm{MPa}$ 。

关 键 词: 多孔陶瓷; $\mathrm{SiC}$; 纳米线; 增材制造; 取向

中图分类号: TQ174 文献标志码: A 